\title{
Pengaruh tingkat pendidikan masyarakat terhadap upaya pemeliharaan gigi tiruan di Kelurahan Upai Kecamatan Kotamobagu Utara
}

\author{
${ }^{1}$ Randa S. Mokoginta \\ ${ }^{2}$ Vonny N. S. Wowor \\ ${ }^{3}$ Hendri Opod
}

\author{
${ }^{1}$ Kandidat Skripsi Program Studi Pendidikan Dokter Gigi Fakultas Kedokteran \\ ${ }^{2}$ Program Studi Pendidikan Dokter Gigi Fakultas Kedokteran \\ ${ }^{3}$ Bagian Psikologi Fakultas Kedokteran \\ Universitas Sam Ratulangi Manado \\ Email: mokogintaranda@gmail.com
}

\begin{abstract}
Denture appliances is not just as a replacement for any kind of tooth loss but it is also a necessary to keep the hygiene and maintenance of the denture appliance, therefore, the denture appliances will not cause any bad effects on oral health. Knowledge of how to keep the denture appliance clean could be represented by a positive attitude through cleaning one's denture appliance. This study was aimed to analyze the effect of education level on the maintenance efforts of denture appliances among denture users in Upai, North Kotamobagu.This was an analytical descriptive study with a cross-sectional design. Samples were obtained by using total sampling method. The instrument of this study was a valid and reliable questionnaire. Data were analyzed with the Chi-Square test. This study was conducted from February to August 2016. The results showed that $41.9 \%$ of the samples had moderate level of education; $47.1 \%$ had low education; and $11 \%$ had high education. In keeping their denture appliances clean, there were $74.2 \%$ that had moderate efforts; $13,6 \%$ had bad efforts; and $12.2 \%$ had good efforts. The Chisquare test showed a $p$ value of $0.001(p<0.05)$. Conclusion: Most of the denture users were lowlevel educated, however, most of them had moderate efforts in keeping their dentures clean.
\end{abstract}

Keywords: education level of society, maintenance efforts of denture appliances.

\begin{abstract}
Abstrak: Penggunaan gigi tiruan tidak hanya sebatas penggantian gigi yang hilang tetapi harus memperhatikan pemeliharaan kebersihannya agar tidak berdampak buruk bagi kesehatan rongga mulut. Pengetahuan yang baik dari masyarakat akan membentuk sikap positif dan diwujudkan melalui tindakan pemeliharaan gigi tiruan. Penelitian ini bertujuan untuk menganalisis pengaruh tingkat pendidikan masyarakat terhadap upaya pemeliharaan gigi tiruan di Kelurahan Upai Kecamatan Kotamobagu Utara. Jenis penelitian ialah deskriptif analitik dengan desain potong lintang. Populasi penelitian yakni masyarakat pengguna gigi tiruan lepasan (GTL) di Kelurahan Upai Kecamatan Kotamobagu Utara sebanyak 155 orang. Teknik pengambilan sampel menggunakan metode total sampling. Instrumen penelitian berupa kuesioner yang telah dilakukan uji validitas dan reliabilitas. Analisis hasil penelitian digunakan uji statistic ChiSquare. Hasil penelitian menunjukkan 41,9\% masyarakat kelurahan Upai memiliki tingkat pendidikan sedang, 47,1\% memiliki tingkat pendidikan rendah, dan $11 \%$ memiliki tingkat pendidikan tinggi. Terdapat $74,2 \%$ memiliki upaya yang cukup dalam pemeliharaan gigi tiruan, 13,6\% buruk, dan 12,2\% baik. Hasil uji Chi Square mendapatkan $\mathrm{p}=0,001(\mathrm{p}<0,05)$. Simpulan:: Tingkat pendidikan masyarakat pengguna gigi tiruan umumnya tergolong rendah tetapi memiliki upaya yang cukup dalam pemeliharaan gigi tiruan. Juga terdapat pengaruh bermakna dari tingkat pendidikan masyarakat terhadap upaya pemeliharaan gigi tiruan.
\end{abstract}

Kata kunci: tingkat pendidikan masyarakat, upaya pemeliharaan gigi tiruan. 
Gigi berperan penting bagi penampilan seseorang, di samping untuk fungsi pengunyahan serta fungsi bicara. Gangguan pada gigi seperti karies, penyakit periodontal dan trauma dapat mengakibatkan terjadinya kehilangan gigi. $^{1}$ Kehilangan gigi dapat berdampak emosional akibat terganggunya fungsi bicara, pengunyahan, dan estetika. ${ }^{2}$ Penggunaan gigi tiruan untuk menggantikan gigi yang hilang penting dilakukan untuk mengembalikan kondisi fungsional dan estetika pasien. ${ }^{3}$

Saat ini kesadaran masyarakat akan kesehatan gigi sudah semakin meningkat. Hal ini memungkinkan meningkatnya penggunaan gigi tiruan sebagai pengganti gigi yang hilang. ${ }^{4}$ Berdasarkan data Riset Kesehatan Dasar (Riskesdas), persentase masyarakat yang menerima perawatan dari tenaga medis gigi termasuk di dalamnya pemasangan gigi tiruan meningkat dari 29,6\% pada tahun 2007 menjadi 31,1\% pada tahun $2013 .{ }^{5.6}$ Hal ini menunjukkan bahwa pengetahuan dan kesadaran masyarakat akan pentingnya gigi tiruan sudah semakin baik namun pengunaan gigi tiruan tidak hanya sebatas penggantian gigi yang hilang saja, tetapi juga harus dipelihara kebersihannya. Gigi tiruan yang tidak dipelihara kebersihannya, akan menghadirkan masalah baru di rongga mulut.

Beberapa masalah yang timbul akibat pemeliharaan gigi tiruan yang kurang baik antara lain karies, gingivitis, penyakit periodontal, dan denture stomatitis. Angka kejadian denture stomatitis di Indonesia cukup tinggi. Penelitian yang dilakukan oleh Marwati (2003) menunjukkan hampir $50 \%$ pengguna gigi tiruan terdeteksi adanya candida albicans, sedangkan penelitian oleh Sudarmawan (2009) menunjukkan $32,2 \%$ dari 30 pengguna gigi tiruan juga terdeteksi adanya candida albicans. ${ }^{7}$ Adanya candida albicans pada pengguna gigi tiruan meningkatkan risiko denture stomatitis karena candida albicans merupakan salah satu penyebab utama terjadinya denture stomatitis. ${ }^{8}$ Penelitian yang dilakukan oleh Lahama et al. ${ }^{8}$ (2015) di Kota Manado menunjukkan persentase masyarakat penderita denture stomatitis sebesar $83,95 \%$. Penelitian yang dilakukan oleh Fernatubun et al. ${ }^{9}$ di Manado (2014) menunjukkan persentase gingivitis sebesar $48,6 \%$ dan periodontitis $18,1 \%$ pada masyarakat pengguna gigi tiruan. Terjadinya beberapa masalah ini berkaitan erat dengan perilaku masyarakat pengguna gigi tiruan yang meliputi pengetahuan, sikap dan tindakan dalam pemeliharaan gigi tiruan.

Pembentukan perilaku diawali dengan adanya paparan pengetahuan atau informasi bagi individu yang selanjutnya berkembang membentuk sikap dan tindakan. Pengetahuan yang baik dan benar yang dimiliki seseorang tentang pemeliharaan gigi tiruan akan menghasilkan sikap positif terhadap pemeliharan gigi tiruan sehingga memberi pengaruh yang baik dan diwujudkan melalui tindakan. ${ }^{9}$ Salah satu sumber pengetahuan berasal dari pendidikan. Pada setiap tahap pendidikan individu akan memiliki pengetahuan yang berbeda-beda pula. Semakin tinggi tingkat pendidikan seseorang, maka akan semakin mudah untuk menyerap informasi. ${ }^{4}$ Penelitian yang dilakukan oleh Titjo et al. di Kelurahan Bahu Kota Manado (2013) menunjukkan bahwa faktor pendidikan berpengaruh dalam keberhasilan pemeliharaan gigi tiruan. ${ }^{9}$ Individu dengan tingkat pendidikan yang tinggi akan lebih mengerti cara memelihara gigi tiruan serta kebersihan gigi dan mulut dibandingkan dengan individu dengan tingkat pendidikan yang rendah.

Kelurahan Upai terletak di dataran tinggi wilayah Utara Kota Kotamobagu dengan jumlah penduduk sebesar 2320 jiwa dan sebagian besar penduduk bermata pencaharian sebagai petani dan pengendara becak motor (bentor) dengan kondisi ekonomi menengah ke bawah. Masyarakat di Kelurahan Upai terdiri dari berbagai tingkatan pendidikan mulai dari lulusan Sekolah Dasar sampai lulusan Perguruan Tinggi. Data survei awal di Kelurahan Upai menunjukkan jumlah masyarakat lulusan tingkat pendidikan dasar masih sangat tinggi dan terdapat banyak pengguna gigi 
tiruan. Pada pengamatan penulis ditemukan pula kondisi kebersihan gigi tiruan yang masih tergolong buruk pada beberapa masyarakat pengguna gigi tiruan di Kelurahan Upai.

Penelitian ini bertujuan untuk mengetahui pengaruh tingkat pendidikan masyarakat terhadap upaya pemeliharaan gigi tiruan di Kelurahan Upai Kecamatan Kotamobagu Utara.

\section{BAHAN DAN METODE PENELITIAN}

Jenis penelitian ini ialah deskriptif analitik dengan desain potong lintang. Penelitian dilaksanakan di Kelurahan Upai Kecamatan Kotamobagu Utara pada bulan Februari-September 2016. Respomdem dalam penelitian ini ialah masyarakat Kelurahan Upai yang menggunakan gigi tiruan lepasan (penuh dan sebagian) berjumlah 155 orang yang telah memenuhi kriteria inklusi. Pengambilan sampel menggunakan metode total sampling.

Instrumen penelitian ialah kuesioner. Responden diminta untuk melakukan pengisian kuesioner yang meliputi pertanyaan tentang variabel penelitian berupa jenjang pendidikan serta bentuk upaya pemeliharaan gigi tiruan. Pengukuran variabel upaya pemeliharaan gigi tiruan dilakukan dengan menggunakan kuesioner yang berisi 6 butir pernyataan. Skala pengukuran menggunakan skala Guttman dimana setiap pernyataan diberi skor 2 untuk jawaban ya dan skor 1 untuk jawaban tidak. Skor terendah ialah 6 dan skor tertinggi ialah 12. Pengolahan dan analisis data menggunakan SPSS versi 16 yang disajikan dalam bentuk tabel.

\section{HASIL PENELITIAN}

Karakteristik respoden penelitian ini dapat dilihat pada Tabel 1-4.

Tabel 1. Distribusi frekuensi responden berdasarkan jenis kelamin

\begin{tabular}{ccc}
\hline Jenis kelamin & $(\mathbf{n})$ & $(\boldsymbol{\%})$ \\
\hline Laki-laki & 52 & 33,6 \\
Perempuan & 103 & 66,4 \\
Total 155100 & & \\
\hline
\end{tabular}

Tabel 2. Distribusi frekuensi responden berdasarkan jenis pekerjaan

\begin{tabular}{ccc}
\hline Pekerjaan & n & \% \\
\hline Tidak bekerja & 80 & 51,6 \\
PNS/Pensiunan PNS & 19 & 12,3 \\
Honorer & 12 & 7,7 \\
Swasta & 26 & 16,8 \\
Petani & 16 & 10,3 \\
Pegawai Swasta & 2 & 1,3 \\
Total & 155 & 100 \\
\hline
\end{tabular}

Tabel 3. Distribusi frekuensi responden berdasarkan tingkat pendidikan

\begin{tabular}{ccc}
\hline Tingkat pendidikan & $\mathbf{n}$ & \% \\
\hline Rendah & 73 & 47,1 \\
Sedang & 65 & 41,9 \\
Tinggi & 17 & 11 \\
Total & 155 & 100 \\
\hline
\end{tabular}

Tabel 4. Distribusi frekuensi berdasarkan upaya pemeliharaan gigi tiruan

\begin{tabular}{ccc}
\hline $\begin{array}{c}\text { Upaya pemeliharaan } \\
\text { gigi tiruan }\end{array}$ & $\mathbf{n}$ & $\mathbf{\%}$ \\
\hline Buruk & 21 & 13,6 \\
Cukup & 115 & 74,2 \\
Baik & 19 & 12,2 \\
Total & 155 & 100 \\
\hline
\end{tabular}

Tabel 5. Distribusi upaya pemeliharaan gigi tiruan berdasarkan tingkat pendidikan responden.

\begin{tabular}{|c|c|c|c|c|c|c|c|c|}
\hline \multirow{2}{*}{$\begin{array}{l}\text { Tingkat } \\
\text { pendidikan } \\
\text { responden }\end{array}$} & \multicolumn{6}{|c|}{ Upaya pemeliharaan gigi tiruan } & \multirow{2}{*}{\multicolumn{2}{|c|}{ Total $(\%)$}} \\
\hline & Buruk & $(\%)$ & Cukup & $(\%)$ & Baik & $(\%)$ & & \\
\hline Rendah & 17 & 23,3 & 51 & 69,9 & 5 & 6,8 & 73 & 100 \\
\hline Sedang & 4 & 6,2 & 52 & 80 & 9 & 13,8 & 65 & 100 \\
\hline Tinggi & 0 & 0 & 12 & 70,6 & 5 & 29,4 & 17 & 100 \\
\hline
\end{tabular}


Mokoginta, Wowor, Opod: Pengaruh tingkat pendidikan...

Tabel 6. Output Uji Chi-Square

\begin{tabular}{cccc}
\hline & Value & Df & Asymp. Sig (2-sided) \\
\hline Pearson Chi Square & $13,303^{\text {a }}$ & 2 &, 001 \\
Likelihood ratio & 14,051 & 2 &, 001 \\
Linear-by-Linear & 12,198 & 1 &, 000 \\
Association & 155 & & \\
N of Valid Cases & & & \\
\hline
\end{tabular}

\section{BAHASAN}

Hasil penelitian yang didapatkan menunjukkan lebih banyak responden perempuan dibandingkan responden lakilaki, yaitu sebanyak $66,4 \%$ dari jumlah keseluruhan responden. Dengan demikian hasil penelitian akan lebih menunjukkan adanya pengaruh karakteristik jenis kelamin perempuan dibandingkan jenis kelamin laki-laki. Jumlah responden perempuan yang lebih dominan mungkin disebabkan karena biasanya perempuan lebih memperhatikan penampilannya dibandingkan laki-laki. Pada kondisi dimana terjadi kehilangan gigi pada perempuan, terlebih kehilangan pada gigi depan, umumnya perempuan akan berusaha untuk segera menggantikan gigi yang hilang dengan gigi tiruan. ${ }^{10}$

Responden yang tidak bekerja merupakan yang terbanyak $(51,6 \%)$ dan seluruhnya merupakan ibu rumah tangga sedangkan jumlah terkecil (1,3\%) merupakan pegawai swasta.

Berdasarkan tingkat pendidikan, diperoleh jumlah terbanyak memiliki tingkat pendidikan rendah $(47,1 \%)$ sedangkan jumlah terkecil ialah tingkat pendidikan tinggi sebesar $(11 \%)$. Hasil yang diperoleh menunjukkan bahwa ada keselarasan antara kondisi ekonomi dan tingkat pendidikan responden.Tingkat pendidikan sebagian besar responden yang masih rendah turut memengaruhi kondisi ekonominya yang juga rendah. Hal ini terlihat dari kehidupan keseharian responden tergolong cukup rendah.

Pendidikan merupakan salah satu faktor yang dapat memengaruhi tingkat pengetahuan individu. Melalui proses pendidikan seorang individu akan memperoleh suatu pengetahuan yang lebih tinggi.
Status ekonomi seseorang juga akan memengaruhi pengetahuan. ${ }^{11}$ Seseorang dengan status ekonomi tinggi akan lebih memiliki kesempatan untuk memperoleh tingkat pendidikan yang lebih baik, yang dapat berpengaruh pada tingkat pengetahuan yang dimiliki. ${ }^{12}$ Hal ini didukung oleh hasil penelitian yang dilakukan oleh Febrianto $^{13}$ di Yogyakarta yang menunjukkan 63,2\% responden dengan status ekonomi tinggi memiliki tingkat pengetahuan yang tinggi (86,8\%). Responden dengan tingkat pendidikan rendah secara umum memiliki pengetahuan yang kurang termasuk pengetahuan dalam bidang kesehatan gigi secara umum. Individu yang mengecap pendidikan dasar biasanya terbatas pengetahuannya dan juga terbatas kemampuannya dalam memahami informasi yang ada. Tingkat pendidikan memengaruhi proses belajar, semakin tinggi tingkat pendidikan seseorang, semakin mudah orang tersebut menerima informasi baik dari orang lain maupun dari media massa. ${ }^{14}$ Semakin banyak informasi yang diterima, maka semakin banyak pula pengetahuan yang dimiliki individu.

Hasil penelitian yang dilakukan oleh Esan et al. ${ }^{15}$ menunjukkan bahwa seseorang dengan tingkat pendidikan yang lebih tinggi lebih banyak mendapatkan informasi tentang kesehatan sehingga dapat mencari perawatan gigi lebih awal, dalam hal ini upaya pemeliharaan gigi tiruan.

Tingkat pendidikan yang rendah dan banyaknya responden yang tidak bekerja berdampak juga pada upaya pemeliharaan gigi tiruan dari responden.Berdasarkan hasil penelitian di lapangan didapatkan tingkat pendidikan responden umumnya tergolong pendidikan rendah. Pendidikan yang dimiliki seseorang akan ikut 
memengaruhi kesehatan gigi dan mulut yang bersangkutan. Individu dengan tingkat pendidikan formal yang tinggi mempunyai pengetahuan dan informasi yang lebih baik, sehingga status kesehatan khususnya kesehatan gigi dan mulut individu tersebut akan lebih baik. ${ }^{11} \mathrm{Hal}$ sebaliknya terjadi pada individu dengan tingkat pendidikan yang rendah serta dampaknya pada kesehatan gigi dan mulut. Anggapan ini sejalan dengan hasil penelitian yang dilakukan oleh Muluwere et al. ${ }^{16} \mathrm{di}$ Manado yang menunjukkan sebanyak $66,7 \%$ masyarakat berpendidikan rendah dengan kondisi status kesehatan gigi dan mulut yang buruk sebesar 53,3\%. Rendahnya tingkat pendidikan yang berdampak pada kondisi ekonomi individu, akan menyebabkan individu mengalami kesulitan untuk mengakses informasi. Saat ini teknologi informasi yang sudah sedemikian majunya, sehingga memudahkan orang untuk mendapatkan berbagai informasi termasuk informasi atau pengetahuan di bidang kesehatan gigi dan mulut. Status ekonomi yang rendah dapat menyebabkan hambatan untuk memperoleh pengetahuan atau informasi, sehingga berpengaruh pada pembentukan perilaku kesehatan individu.

Tabel 5 menunjukkan gambaran tingkat pendidikan responden dan upaya pemeliharaan gigi tiruan yang digunakannya. Semakin tinggi tingkat pendidikan, terlihat bahwa persentase upaya pemeliharaan gigi tiruan yang baik semakin meningkat. Sebaliknya semakin rendah tingkat pendidikan responden maka upaya pemeliharaan gigi tiruan yang buruk semakin meningkat. Hasil penelitian ini juga didukung oleh hasil uji statistik $C h i$ Square dengan perolehan nilai $p=0,001$ $(<0,05)$, yang berarti terdapat pengaruh bermakna dari tingkat pendidikan masyarakat terhadap upaya pemeliharaan gigi tiruan.

Yang menarik dari hasil penelitian pada Tabel 4 yaitu $74,2 \%$ responden memiliki upaya yang cukup dalam pemeliharaan gigi tiruan dan hal ini juga sejalan dengan hasil pada Tabel 5 yang menunjukkan bahwa $69,9 \%$ responden dengan tingkat pendidikan rendah memiliki upaya pemeliharaan gigi tiruan yang tergolong cukup. Menurut asumsi penulis tingkat pendidikan bukanlah satu-satunya faktor yang memengaruhi perilaku individu. Perilaku individu berupa upaya pemeliharaan gigi tiruan dapat dipengaruhi oleh faktor lainnya, meskipun tingkat pendidikan bisa dikatakan sebagai salah satu faktor yang sangat berpengaruh pada pembentukan perilaku.. Faktor yang turut memengaruhi sehingga banyak responden memiliki upaya cukup dalam pemeliharaan gigi tiruan ialah lingkungan sekitar responden dan media massa. Hal ini didukung oleh penelitian yang dilakukan oleh Tuerah et al. ${ }^{17}$ di Manado yang menyebutkan hal yang mendorong seseorang dalam perawatan gigi tiruan adalah lingkungan keluarga dan media massa.

Lingkungan sekitar individu merupakan faktor lainnya yang memiliki peranan penting dalam membentuk perilaku individu. Responden bisa mendapatkan informasi atau mencontoh dari individu atau keluarga lainnya di sekitar tempat tinggal, yang memiliki pendidikan lebih tinggi dan memakai gigi tiruan. Faktor lainnya yang menurut penulis juga cukup memberikan pengaruh yaitu media massa. Media massa yang dimaksudkan ialah media elektronik dan media cetak. Responden bisa mendapat informasi melalui televisi dan koran yang sudah banyak menampilkan cara pemeliharaan kebersihan gigi dan mulut termasuk cara pemeliharaan gigi tiruan. Media elektronik yaitu televisi yang dulunya termasuk kebutuhan mewah sekarang tidak lagi, karena di zaman yang sudah semakin modern seperti sekarang ini televisi sudah menjadi kebutuhan pokok bagi hampir sebagian besar masyarakat. Asumsi penulis didukung oleh hasil penelitian yang dilakukan Mulyono ${ }^{18}$ di Kota Semarang yang menyebutkan 92,31\% keluarga miskin di Kecamatan Gajahmungkur memiliki televisi.

Kondisi ekonomi sebagian besar 
responden yang masih tergolong rendah tidak menjadi alasan bagi responden untuk tidak memiliki televisi di rumah, karena bagi responden televisi sudah merupakan kebutuhan yang harus dipenuhi. Dengan demikian tingkat pendidikan bukan satusatunya faktor yang berpengaruh pada perilaku individu, dalam hal ini upaya pemeliharaan gigi tiruan responden yang diteliti. Faktor-faktor inilah menurut penulis yang membuat sebagian besar responden memiliki upaya pemeliharaan gigi tiruan yang tergolong cukup.

\section{SIMPULAN}

Dari hasil penelitian pada masyarakat

di Kelurahan Upai dapat disimpulkan bahwa:

1. Tingkat pendidikan pengguna gigi tiruan umumnya tergolong rendah.

2. Masyarakat yang menggunakan gigi tiruan umumnya memiliki upaya yang cukup dalam pemeliharaan gigi tiruan.

3. Terdapat pengaruh tingkat pendidikan masyarakat terhadap pemeliharaan gigi tiruan

\section{SARAN}

1. Diharapkan pemerintah memperhatikan dan mengupayakan adanya perbaikan tingkat pendidikan masyarakat dengan memberikan kesempatan bagi masyarakat kurang mampu untuk memperoleh pendidikan yang lebih tinggi.

2. Doharapkan dinas kesehatan dan puskesmas setempat agar lebih proaktif dalam melakukan penyuluhan pada masyarakat khususnya pada masyarakat

\section{DAFTAR PUSTAKA}

1. Jubhari EH. Upaya untuk mengurangi preparasi gigi: Fung Shell Bridge. Dentofasial Journal. 2007;6(1):2.

2. Suresh S, Sharma S. A clinical survey to determine the awareness and preference of needs of a complete denture among complete edentulous patients. J Int Oral Health. 2010;2(3):67.

3. Rahmayani L, Herwanda, Idawani $M$. Perilaku pemakai gigi tiruan terhadap pemeliharaan gigi tiruan lepasan.
Jurnal PDGI. 2013;62(3):83.

4. Arifah N. Hubungan antara tingkat pendidikan dan pengetahuan pasien terhadap pemeliharaan gigi tiruan sebagian lepasan di rumah sakit gigi dan mulut Prof.Soedomo [Skripsi]. Yogyakarta: Fakultas Kedokteran Gigi Universitas Gadjah Mada; 2015.

5. Depertemen Kesehatan Republik Indonesia. Laporan Riset Kesehatan Dasar Nasional 2007. Jakarta: Badan Penelitian dan Pengembangan Kesehatan, Desember 2008; p. 176.

6. Depertemen Kesehatan Republik Indonesia. Laporan Riset Kesehatan Dasar Nasional 2013. Jakarta: Badan Penelitian dan Pengembangan Kesehatan, 2013; p. 149.

7. Sugianitri NI. Ekstrak biji buah pinang (Areca catechu L.) dapat menghambat pertumbuhan koloni candida albicans secara in vitro pada resin akrilik heat cured [Tesis]. Denpasar: Universitas Udayana; 2011.

8. Lahama L, Wowor VNS, Waworuntu OA. Angka kejadian stomatitis yang diduga sebagai denture stomatitis pada pengguna gigi tiruan di kelurahan Batu Kota Manado. Pharmacon. 2015;4(4):77-9.

9. Fernatubun CA, Pangemanan DHC, Wowor VNS. Gambaran kerusakan gigi penyangga pada pengguna gigi tiruan sebagian lepasan di kelurahan Batu Kota. eG. 2015;3(1):93.

10.Liwongan GB, Wowor VNS, Pangemanan DHC. Persepsi pengguna gigi tiruan lepasan terhadap pemeliharaan kebersihan gigi dan mulut. Pharmacon.2015;4(4):209.

11.Bagaray DA, Mariati NW, Leman MA. Perilaku memelihara kebersihan gigi tiruan lepasan berbasis akrilik pada masyarakat desa treman kecamatan kauditan. eG. 2014;2(2):8.

12.Yulianti RP, Muhlisin A. Hubungan antara pengetahuan orang tua tentang kesehatan gigi dan mulut dengan kejadian karies gigi pada anak di SDN V Jaten Karanganyar. Berita Ilmu Keperawatan. 2011;4(1):29.

13.Febrianto ID. Hubungan tingkat penghasilan, tingkat pendidikan dan tingkat pengetahuan orang tua tentang 
makanan bergizi dengan status gizi siswa TK Islam Zahrotul Ulum Karangampel Indramayu [Skripsi]. Yogyakarta: Fakultas Ilmu Keolahragaan Universitas Negeri Yogyakarta; 2012.

14. Aulia DK, Hadnyanawati H, Kristiana D. Hubungan pengetahuan pemeliharaan gigi tiruan lengkap terhadap kebersihan gigi tiruan pasca insersi. Pustaka Kesehatan. 2016;4(1):42.

15.Esan TA, Olusile AO, Akeredolu PA and Esan AO. Sociodemographic factors and edentulism the Nigerian experience. BMC Oral Health. 2004 [Cited 2016 Oktober 31];4(3): 1-6 Available from: URL: http://www. biomedcentral.com/1472-6831/4/3

16. Muluwere VO, Mariati NW, Wicaksono

DA. Gambaran pengetahuan dan status kebersihan mulut pada pemakai gigi tiruan sebagian lepasan di Kelurahan Batu Kota Kecamatan Malalayang. e-G. 2015;3(1):199.

17.Tuerah T, Wowor VNS, Pangemanan DHC. Hubungan status ekonomi dengan sikap pasien terhadap perawatan gigi tiruan. Pharmacon. 2016;5(1):66.

18.Mulyono SE. Model pemberdayaan masyarakat miskin melalui jalur pendidikan non formal di Kecamatan Gajahmungkur Kota Semarang. Jurnal Unnes. 2011;1:4. 